\title{
High-quality Development Paths of Manufacturing Industry Based on Industrial Convergence
}

\author{
Yongkang Liang ${ }^{1 *}$, Xiaoqing Luo ${ }^{1}$ \\ ${ }^{1}$ School of Economics and Management, Yan' an University, Yan' an 716000, China
}

\begin{abstract}
Industrial convergence is the key to achieving high-quality development of manufacturing industry. Based on the analysis of the development situation and convergence level of China's manufacturing and producer service industry, this paper proposed four paths for the high-quality development of manufacturing from the perspective of industrial convergence: the convergence of research and design factor, the convergence of information technology factor, manufacturing servitization, and service-oriented reverse manufacturing. The conclusion provided some theoretical guidance for the development of manufacturing industry.
\end{abstract}

\section{Introduction}

Industrial convergence is an important driving force for achieving high-quality development of manufacturing industry. The idea of industrial convergence originated from the concept of technological convergence proposed by Rosenberg (1963), the same technology can be adopted between different industries to achieve technology penetration [1]. Many scholars have carried out research on the connotation, measurement and effect of industrial convergence. The industrial convergence in this paper refers specifically to the convergence of manufacturing industry and producer service industry. The production service industry is a service that can be used for the further production of goods and services and is not a service for final consumption [2]. It has a trend of continuous separation from the manufacturing industry and deep integration in business. Based on the perspective of industrial convergence, this paper explored the paths to achieve high-quality development of the manufacturing industry.

\section{Present Situation Analysis}

The manufacturing industry is the mainstay of the national economy and has always occupied an important position in the China's economy. According to the data from the National Bureau of Statistics [3], the value-added of China's manufacturing increased by $8.7 \%$ annually from 2016 to 2019, from 20950.89 billion yuan (RMB) to 26917.51 billion yuan (RMB), as shown in Figure 1, accounting for $28.1 \%$ of the global total. In 2020 , the value-added of China's manufacturing industry increased by $3.4 \%$ over 2019 . The 3.27 million manufacturing enterprises created 105 million jobs, accounting for 27.3 percent of the total employment. In recent years, China's manufacturing industry has made remarkable achievements in terms of scale advantages, labor productivity, and technological innovation [4].

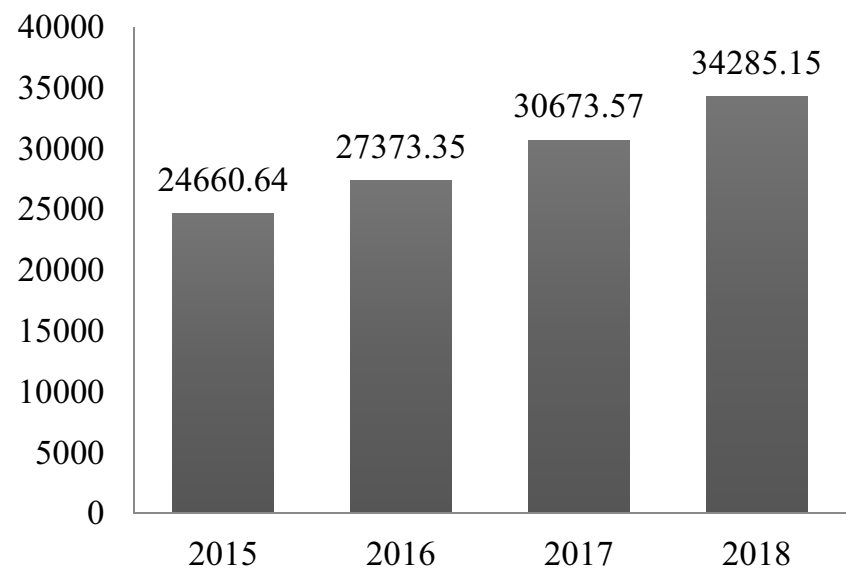

Figure 1. The value-added of manufacturing industry from 2016 to 2019 (Unit: billion yuan). Data source: National Bureau of Statistics: China Statistical Yearbook. 
Producer service industry is an important part of modern service industry, mainly including wholesale and retail, transportation, storage and postal services, information transmission, software and information technology services, finance, real estate, leasing and business services, and scientific research and technology services. According to the data from the National Bureau of Statistics, the value-added of China's producer service industry increased from 24660.64 billion yuan (RMB) in 2015 to 34285.15 billion yuan (RMB) in 2018 , as shown in Figure 2. In 2018, the value-added of the producer service industry accounted for $49.90 \%$ of the service industry[5].

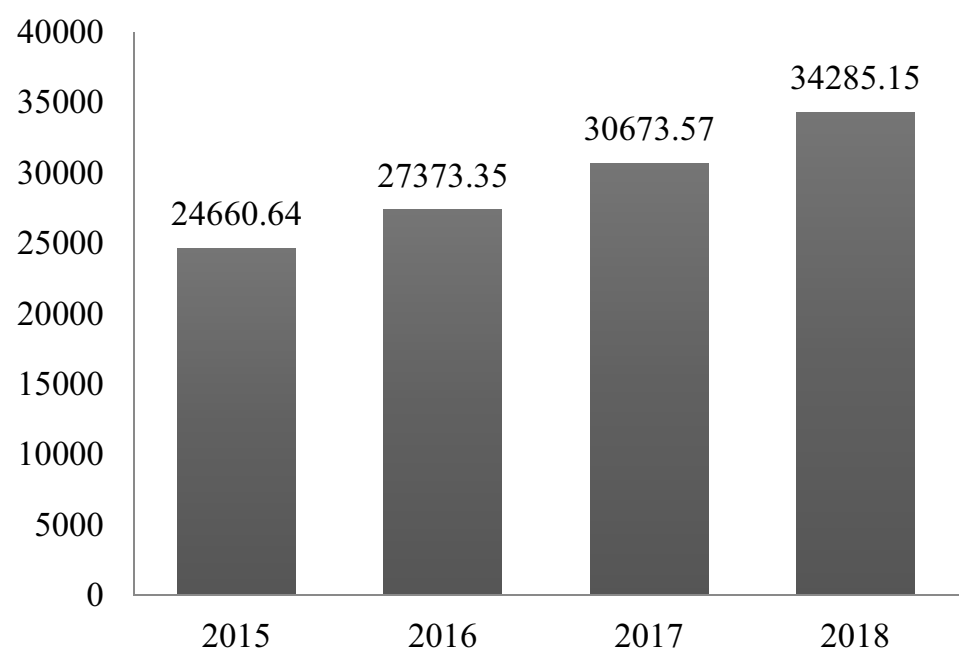

Figure 2. The value-added of producer service industry from 2015 to 2018 (Unit: billion yuan). Data source: National Bureau of Statistics: China Statistical Yearbook.

\section{Industrial Convergence Level Analysis}

Industrial convergence is a new trend of modern industrial development. Promoting the deep convergence of manufacturing and producer services is the key to achieving high-quality development of China's manufacturing industry. Based on the provincial panel data from 2005 to 2018 , Su Y. W. (2020) constructed an industrial convergence measurement model using industrial closeness and industrial development reconciliation index to measure the degree of convergence between manufacturing and producer services in China, and the results are shown in the Figure 3 [6]. It can be seen from the figure that the convergence level between the producer service industry and the manufacturing industry was showing an upward trend, and it rose from "very low convergence " in 2006 to "high convergence " in 2018. In addition, it also showed the characteristics of industry differences, provincial differences and regional differences. So the development of industrial convergence was still unbalanced in China.

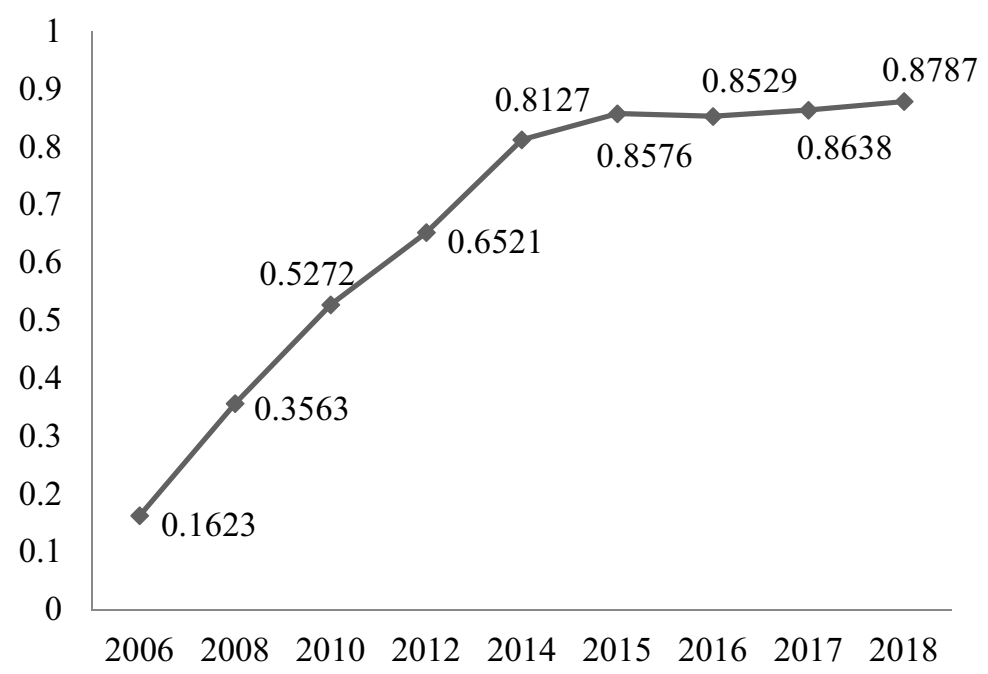

Figure 3. Convergence level of China's manufacturing and producer services. Data source: From reference[6]. 


\section{High-quality Development Path Analysis}

In order to achieve the high-quality development goals of China 's manufacturing industry, this paper proposed four paths based on industrial convergence, as shown in Table 1.

Table1. Four high-quality development paths of manufacturing

\begin{tabular}{|c|c|c|}
\hline Dimension & Input dimension & Output dimension \\
\hline $\begin{array}{c}\text { Realization } \\
\text { path }\end{array}$ & $\begin{array}{c}\text { Research and } \\
\text { design factor }\end{array}$ & $\begin{array}{c}\text { Manufacturing } \\
\text { servitization }\end{array}$ \\
\cline { 2 - 3 } & $\begin{array}{c}\text { Information } \\
\text { technology factor }\end{array}$ & $\begin{array}{c}\text { Reverse } \\
\text { manufacturing }\end{array}$ \\
\hline
\end{tabular}

\subsection{The Convergence of Research and Design Factor}

Through scientific research and technical services, the technological innovation capabilities of manufacturing enterprises have been continuously strengthened. In particular, it highlights the leading role of research and design in the development of the manufacturing industry. Manufacturing enterprises can promote transformation and upgrading through the combination of research and design factor and manufacturing. When adopting this path, the focus can be placed on industrial design, technology research and development, etc.

\subsection{The Convergence of Information Technology Factor}

With the help of the new generation of information technology services, the supporting role of information technology factors to the manufacturing industry has been played. In particular, various digital technologies such as the internet of things, big data, cloud computing and blockchain will be utilized to drive the digital transformation of the manufacturing industry and improve the total factor productivity of the manufacturing industry. When adopting this path, the focus can be placed on intelligent manufacturing, shared manufacturing, etc.

\subsection{The Path of Manufacturing Servitization}

The proportion of service factors can be increased by putting all kinds of service factors in producer services (such as finance, logistics, technology research and development, management consulting, testing and certification.) into manufacturing industry, and then the factor input structure of manufacturing industry is further optimized. Through service-oriented business model innovation, manufacturing enterprises provide the composite products (including products and services) to customers. When adopting this path, the focus can be placed on manufacturing servitization, product service systems, etc.

\subsection{The Path of Reverse Manufacturing}

Through the expansion of the producer service industry to the manufacturing industry, more manufacturing factors can be integrated into the producer service industry, and then the development of manufacturing can be promoted. In particular, relevant service enterprises are encouraged to give full play to the advantages of factors and expand to the manufacturing link. When adopting this path, the focus can be placed on manufacturing service platform, innovation chain management, supply chain management, etc.

\section{Conclusion}

In recent years, China's manufacturing industry and producer service industry have developed rapidly. Although the convergence level was different in industries, provinces, regions, the overall trend was continuously improving. The deep convergence of manufacturing and producer services is the key to promoting high-quality development of manufacturing. From the perspective of investment, there are two paths: the convergence of research and design factor and the convergence of information technology factor. From the perspective of output, there are two paths: manufacturing servitization and reverse manufacturing. The conclusion provided some theoretical guidance for promoting the high quality development of China's manufacturing industry.

\section{Acknowledgments}

This work was financially supported by the "Innovation Capability Support Program of Shaanxi (Program No.2020KRM044)" , "Special Scientific Research Program of Education Department of Shaanxi Provincial Government (Program No.20JK0013)" and " Doctoral research Program of Yan' an University (Program No.YDBK2020-08)".

\section{References}

1. N. Rosenberg, Technological change in the machine tool industry, 1 840-1910. Journal of Economic History, 4(1963)414-443.

2. X. H. Li, Service-oriented manufacturing and transformation and upgrading of China's manufacturing industry, Contemporary Economic Management. 12(2017)30-38.

3. Information on http://www.stats.gov.cn/tjsj/ndsj/

4. T. Lv, D. Liu, High-quality development of manufacturing industry: gaps, problems and measures, Study \& Exploration. 1(2019)111-117. 
5. X. Yan, Research on the development strategy of China's producer service industry, Modern Business Trade Industry.14(2021)32-33.

6. Y.W. Su, A Study on the measurement of the level of integration of producer services and manufacturing: based on provincial panel data from 2005 to 2018 , Macroeconomics. 12(2020)98-108. 